\title{
ANTIDIABETIC EFFECT OF MIKANIA SCANDENS ON ALLOXAN-INDUCED RAT MODEL
}

\author{
RIMASHREE BAISHYA ${ }^{1}$, ANJAN ADHIKARI ${ }^{2}$, SHARMISTHA BISWAS ${ }^{3}$, SOMA BANERJEE ${ }^{1 *}$
}

${ }^{1}$ Department of Biotechnology, Heritage Institute of Technology, Anandapur, Kolkata - 700 107, West Bengal, India. ${ }^{2}$ Department of Pharmacology, R.G. Kar Medical College \& Hospital, Kolkata - 700 004, West Bengal, India. ${ }^{3}$ Department of Anatomy, Malda Medical College, English bazar, Malda - 732 101, West Bengal, India. Email: soma.banerjee@heritageit.edu

\author{
Received: 25 October 2017, Revised and Accepted: 28 November 2017
}

ABSTRACT

Objective: The objective was to study the evaluation of antidiabetic and antioxidant activity of different doses ethanolic extract of Mikania scandens leaves.

Methods: The rats were divided into five groups of six animals each (non-diabetic control, diabetic control, standard drug-treated, and plant treated groups ( 250 and $500 \mathrm{mg} / \mathrm{kg}$ body weight)). Diabetes was induced in the healthy male Wistar rats (150-200 g body weight, 4-6 weeks old) by the administration of alloxan monohydrate $\left(150 \mathrm{mg} / \mathrm{kg}\right.$, i.p.). On the $0^{\text {th }}, 3^{\text {th }}, 7^{\text {th }}, 11^{\text {th }}$, and $15^{\text {th }}$ days, the blood samples were analyzed for blood glucose. The antioxidant and antidiabetic parameters were evaluated by standard protocol. The liver tissue was used for histopathological assessment of liver damage.

Results: The ethanolic extract of leaves of M. scandens showed a significant reduction $(\mathrm{p}<0.001)$ in the blood glucose levels and the antioxidant levels, with $500 \mathrm{mg} / \mathrm{kg}$ of body weight in the alloxan-induced diabetic rats as compared to the controls. Histopathological studies provided evidence that the leaf extract possesses antidiabetic activity.

Conclusions: The ethanolic extract of leaves of $M$. scandens showed potent antidiabetic and antioxidant abilities against alloxan-induced rats, which indicate the presence of hypoglycemic constituents in the plant.

Keywords: Antidiabetic activity, Alloxan, Mikania scandens, Histopathology.

(C) 2018 The Authors. Published by Innovare Academic Sciences Pvt Ltd. This is an open access article under the CC BY license (http://creativecommons. org/licenses/by/4. 0/) DOI: http://dx.doi.org/10.22159/ajpcr.2018.v11i3.23283

\section{INTRODUCTION}

Diabetes mellitus (DM), a group of metabolic disorders that result in hyperglycemia with a disturbance in carbohydrate, fat and protein metabolism which leads to detect in insulin secretion or inefficient insulin action or both [1,2]. Hyperglycemia generates reactive oxygen species which in turn becomes a basis for lipid peroxidation and membrane damage which results in the generation of secondary complications in diabetes. Antioxidants have been found to prevent the destruction of $\beta$-cells by inhibiting the peroxidation chain reaction, and thus they provide protection against the development of diabetes. Savickiene recommended the use of plants and biological active component in this respect to reduce the number of diabetes complications and to postpone their development [3]. Reports of methanolic extracts of plants such as Caralluma fimbriata and Tectona grandis Linn. showed both potent antioxidant and antidiabetic activity $[4,5]$.

Mikania scandens (L.) Willd. (Asteraceae), known as climbing hemp weed, twining herbaceous climbing vine with long-petioled opposite leaves and small homogenous flower-heads, grown as a common weed throughout the plains of India and Bangladesh. Traditionally in the Indian subcontinent, the plant was used for some medicinal purposes like leaf extracts used to treat stomach ulcers and in wound healing [6]. This plant is also used for its eupeptic, antispasmodic, and antimicrobial effects [7-9].

The present study focuses in the phytochemical analysis of M. scandens leaves extracts and to evaluate the antidiabetic activity on alloxaninduced diabetic rats.

\section{METHODS}

\section{Plant decoction preparation}

The leaves were collected from college premise during the month of August-October 2015. The plant was identified from the Department of Botany, University of Calcutta, India. A voucher specimen has been submitted to the University of Calcutta Herbarium with Accession number: 20007-CUH. The leaves were dried at room temperature. The dried leaves were powdered using a grinder to coarse powder, packed into Soxhlet column and then extracted with $70 \%$ ethanol for $24 \mathrm{~h}$. The extract was evaporated to dryness. The obtained crude extract was stored in airtight container in the refrigerator at $-4^{\circ} \mathrm{C}$ for further studies.

\section{Drugs and chemicals}

Alloxan monohydrate was purchased from Sigma Ltd. USA. Glibenclamide (Daonil) manufactured by Sanofi India Limited, India. All other chemicals used in the study were of analytical grade.

\section{Screening and maintenance of animals}

Healthy male Wistar rats (150-200 g body weight, 4-6 weeks old) were used. They were preliminarily screened, and abnormal rats were excluded. Animals were provided with standard diet, and filtered tap water was given ad libitum. Animals were maintained under standard $12 \mathrm{~h}$ dark-light cycle, $60 \pm 10 \%$ humidity and a temperature of $21.5 \pm 1^{\circ} \mathrm{C}$. Coprophagy (and thus re-ingestion of any drug) was prevented by keeping the animals in cages with gratings on the floors. The distribution of animals in the groups was randomized. Freshly prepared solutions of drugs or chemicals were used throughout the study. After completion of the experiments, animals were euthanized with anesthetic ether. All experiments complied with Control and Supervision of Experiments on Animals, India, guidelines for animal experimentation. The protocols used in this study were approved, and Ethical Clearance was obtained from Institutional Animal Ethical Committee.

\section{Preliminary phytochemical screening}

The extract which is obtained was subjected to various qualitative tests for the identification of various plant constituents present in this 
species using simple and standard quantitative methods as described by Trease and Evans [10].

\section{Acute oral toxicity study}

Healthy male Wistar rats (150-200 g body weight) were divided into six groups each consisting of six animals. Group 1 animals were treated with distilled water, and Group 2 to Group 6 animals received $100,250,500,1000$, and $2000 \mathrm{mg} / \mathrm{kg}$ of fresh M. scandens extract, respectively. The animals were observed continuously for the first $3 \mathrm{~h}$ for any toxic manifestation, behavioral and neurological profiles. Thereafter, observations were made at regular intervals for $48 \mathrm{~h}$. They were observed daily for a total of 14 days for observing signs of delayed toxicity. Then, $\mathrm{LD}_{50}$ was calculated [11]

\section{Induction of diabetes}

A single dose of alloxan monohydrate $(150 \mathrm{mg} / \mathrm{kg}, \mathrm{b} . \mathrm{w}$, i.p) was dissolved in normal saline, was given for diabetes induction in the rats after overnight fasting. After $1 \mathrm{~h}$ of alloxan administration, the animals were fed the standard pellets and water ad-libitum. For a week the animals were stabilized and fasting blood samples were withdrawn from tail vein, and blood glucose level was measured using a glucometer (Accuchek, Johnson and Johnson Pvt. Ltd, India). The animals are showing blood glucose levels more than $250 \mathrm{mg} / \mathrm{dl}$ were selected for the study [12].

\section{Antidiabetic experimental design}

The rats were fasted overnight for $12-24 \mathrm{~h}$ were randomly divided into five groups of six rats per group: Non-diabetic control (Group 1), diabetic control (Group 2), standard drug treated with $10 \mathrm{mg} / \mathrm{kg} /$ day of glibenclamide (Group 3) and plant extract treated groups with 250 and $500 \mathrm{mg} / \mathrm{kg}$ body weight (i.e., Group 4 and 5, respectively). During this period, animals in all groups had free access to standard diet and water. Fasting blood was withdrawn from the tail vein, and glucose levels were estimated using glucose oxidase peroxidase strips and a glucometer on $0^{\text {th }}, 3^{\text {rd }}, 7^{\text {th }}, 11^{\text {th }}$, and $15^{\text {th }}$ day of the treatment.

\section{Estimation of biochemical parameters}

On the $15^{\text {th }}$ day, the animal was sacrificed under ether anesthesia, and liver tissue was excised for the assay of antioxidant activity, and a part was fixed in buffered formalin for histopathological assessment of liver damage. Liver damage was assessed by the estimation of antioxidant activities of catalase (CAT), reduced glutathione (GSH), glutathione peroxidase (GPx), and lipid peroxidase (LPx) in the tissue homogenate following standard procedure [13-15].

\section{Statistical analysis}

All the data were represented as means \pm standard deviation (SD) for each group. Statistical analysis was performed by t-test. $\mathrm{p}<0.001,0.01$, and 0.05 was considered to indicate statistically significant.

\section{RESULTS}

Preliminary phytochemical screening of the $M$. scandens revealed the presence of tannins, flavonoids, saponins, terpenoids, glycosides, steroid, and anthraquinones. All rats treated with $M$. scandens showed no behavioral changes up to $2000 \mathrm{mg} / \mathrm{kg}$ by the oral route. No mortality was observed at this dose during 48 hours of administration. In antidiabetic study, the body weight changes were observed to be significantly $(\mathrm{p}<0.01)$ increased in the following groups; 3,4 , and 5 (i.e. $6.55 \%, 8.08 \%$, and $6.04 \%$ ) when compared to Group 2 over the period of 14 days, on the contrary, Group 2 showed decrease in the body weight by $19.7 \%$ (Graph 1). In Groups 3, 4, and 5 blood glucose level found to be reduced significantly $(\mathrm{p}<0.001)$ by $69.09 \%, 50.75 \%$, and $60.33 \%$, respectively, after 14 days of the administration of $M$. scandens in respect to alloxan treated group in which the glucose was found to be increased by $25.82 \%$ (Table 1 ).

Table 2 summarized the estimation of liver enzymes, namely, GSH, GPx, LPX, and CAT. Liver enzyme of the rats was affected after treatment with

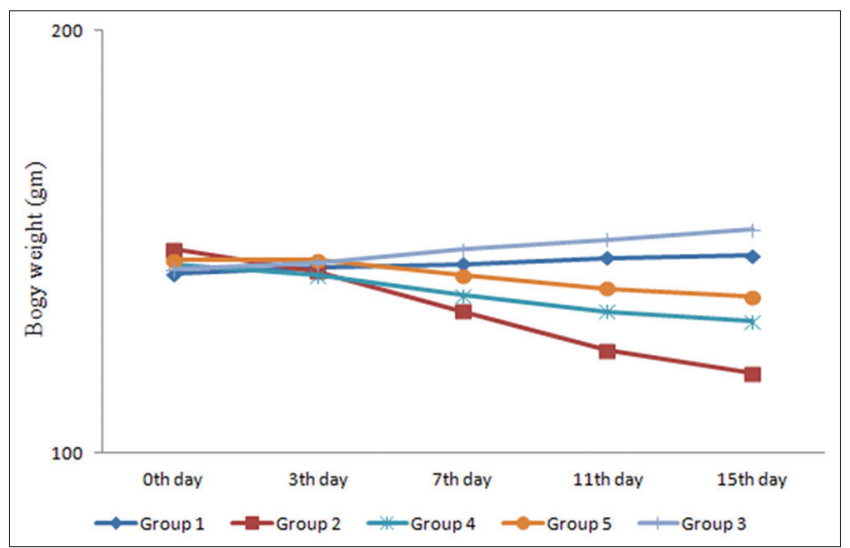

Graph 1: Change in body weight of different groups of rats. Values are expressed as a mean \pm standard deviation. $(n=6)$. $p<0.01$ for all the groups with respect to the control

Table 1: Blood glucose levels in non-diabetic and diabetic rats

\begin{tabular}{|c|c|c|c|c|c|c|}
\hline Group & Treatment & $0^{\text {th }}$ day & $3^{\text {rd day }}$ & $7^{\text {th }}$ day & $11^{\text {th }}$ day & $15^{\text {th }}$ day \\
\hline Group 1 & Normal & $84 \pm 1.58$ & $85 \pm 2$ & $86.2 \pm 0.84$ & $90.8 \pm 1.30$ & $93.6 \pm 1.14$ \\
\hline Group 2 & Alloxan $(150$ mg/kg) & $87 \pm 1.58$ & $287.4 \pm 6.07^{\#}$ & $329 \pm 1 \#$ & $348.2 \pm 5.12^{\#}$ & $361.6 \pm 1.14^{\#}$ \\
\hline Group 3 & Alloxan+glibenclamide (10 mg/k) & $87.6 \pm 1.67$ & $286 \pm 2.12$ & $210 \pm 1.51 * * *$ & $141.1 \pm 2.94 * * *$ & $88.4 \pm 1.58^{* * *}$ \\
\hline Group 4 & Alloxan+Mikania scandens $(250 \mathrm{mg} / \mathrm{kg})$ & $88.8 \pm 1.30$ & $281.8 \pm 2.39$ & $248.6 \pm 2.07^{* *}$ & $209.6 \pm 2.30^{* * *}$ & $138.8 \pm 4.03^{* * *}$ \\
\hline Group 5 & Alloxan+Mikania scandens (500 mg/kg) & $88 \pm 1.41$ & $288.4 \pm 2.70$ & $239.4 \pm 2.41^{* * *}$ & $182 \pm 2.12^{* * *}$ & $114.4 \pm 6.99^{* * *}$ \\
\hline
\end{tabular}

Values are expressed as mean $\pm \mathrm{SD}(\mathrm{n}=6) .{ }^{*} \mathrm{p}<0.001$ considered statistically significant as compared to normal group. ${ }^{* *} \mathrm{p}<0.01$ considered statistically significant as compared to diabetic group. ${ }^{* *} \mathrm{p}<0.001$ considered statistically significant as compared to diabetic group. SD: Standard deviation

Table 2: Effect on liver enzyme GSH ( $\mu \mathrm{g}$ of GSH consumed/min/mg protein), GPx ( $\mu \mathrm{g}$ of GSH consumed/min/mg protein), LPx ( $\mu$ M/g tissue), CAT ( $\mu \mathrm{M}$ of $\mathrm{H} 202 / \mathrm{mg}$ protein/)

\begin{tabular}{|c|c|c|c|c|c|}
\hline Group & Treatment & GSH & GPx & LPX & CAT \\
\hline Group 1 & Normal & $0.244 \pm 0.005$ & $0.755 \pm 0.002$ & $0.059 \pm 0.001$ & $0.224 \pm 0.005$ \\
\hline Group 2 & Alloxan $(150 \mathrm{mg} / \mathrm{kg})$ & $0.172 \pm 0.004^{\#}$ & $0.451 \pm 0.003^{\#}$ & $0.141 \pm 0.001^{\#}$ & $0.073 \pm 0.002^{\#}$ \\
\hline Group 3 & Alloxan+Glibenclamide (10 mg/kg) & $0.304 \pm 0.018^{* * *}$ & $0.821 \pm 0.004^{* * *}$ & $0.045 \pm 0.002^{* * *}$ & $0.314 \pm 0.034^{* * *}$ \\
\hline Group 4 & Alloxan+Mikania scandens (250 mg/kg) & $0.232 \pm 0.002^{* * *}$ & $0.705 \pm 0.005^{* * *}$ & $0.062 \pm 0.001^{* * *}$ & $0.24 \pm 0.026^{* * *}$ \\
\hline Group 5 & Alloxan+Mikania scandens $(500 \mathrm{mg} / \mathrm{kg})$ & $0.242 \pm 0.015^{* * *}$ & $0.767 \pm 0.001^{* * *}$ & $0.057 \pm 0.001^{* * *}$ & $0.286 \pm 0.010^{* * *}$ \\
\hline
\end{tabular}

Values are expressed as mean $\pm \mathrm{SD}(\mathrm{n}=6)$. $\mathrm{p} p<0.001$ considered statistically significant as compared to normal group. ${ }^{* *} \mathrm{p}<0.01$ considered statistically significant as compared to diabetic group. ${ }^{* * *}<<0.001$ considered statistically significant as compared to diabetic group. CAT: Catalase, GSH: Reduced glutathione, GPx: Glutathione peroxidase, LPx: Lipid peroxidase, SD: Standard deviation 
alloxan. A significant increase $(\mathrm{p}<0.001)$ in the activities of enzymes level occurred in 14 days of exposure in Groups 3, 4, and 5 when compared with a diabetic. LPx levels were significantly $(\mathrm{p}<0.001)$ reduced in all treated groups in comparison to the Group 2. It was most significantly reduced in group 3 animals, i.e. $68.09 \%$, followed by Groups 5 and 4 to $59.57 \%$ and $56.03 \%$ s respectively. Levels of CAT were increased significantly $(\mathrm{p}<0.001)$ in all treated groups. Similar observations were seen in case of GSH and GPx level in Group 3, Group 4, and Group 5.

Results of histopathological studies provided supportive evidence for biochemical analysis. Histology of liver section of normal animal exhibited the normal architecture of the classic hepatic lobules. The hepatocytes form branching, and anastomosing cords are radiating from the central vein. The cells appeared to be separated by the blood sinusoids that were seen to be lined by flat endothelial cells (Fig. 1), whereas that of alloxan intoxicated animals shown enlargement and congestion of central vein of whole liver, nuclear enlargement of hepatocytes, enlargement of sinusoids, and erythrocyte accumulation in portal veins (Fig. 2). The liver sections of the rats treated with alloxan and M. scandens $250 \mathrm{mg} / \mathrm{kg}$ (group 4) shows infiltration of mononuclear cells (plasmocytes) in the portal area marked by an arrow. Reduction of enlargement of central veins and erythrocyte accumulation, enlargement and congestion of sinusoids, congestion and enlargement in portal veins with mononuclear cell infiltration was observed when compared with the diabetic group. Plasmocyte infiltration observed in this group revealed inflammatory reaction (Fig. 3). In alloxan and M. scandens $500 \mathrm{mg} / \mathrm{kg}$ (group 5) dose liver histology almost reverted back to normal; few plasmocytes infiltration in portal area was noted. The group receiving the standard drug, normal histology of liver observed.

\section{DISCUSSION}

The pancreas is the primary organ which senses the organism's dietary and energetic states through blood glucose concentration and in response to elevated blood glucose, insulin secreted [16]. Alloxan is an oxygenated pyrimidine derivative beta cytotoxin that causes $\beta$-cells destruction of the islets of Langerhans resulting in reduced synthesis and release of insulin which leads to diabetes or hyperglycemia [17]. In this study, administration of alloxan $(150 \mathrm{mg} / \mathrm{kg})$ the pancreatic beta cells produced a partial destruction, even though the animals are permanently diabetic. Thus, the beta cells of these animals had surviving, and regeneration was possible [18] and the increased serum glucose levels when compared to normal animals and also induced persistent DM in rats. Several studies have indicated that diabetic $\beta$-cells generate oxygen free radicals and that the overexpression of antioxidant enzymes, such SOD, CAT, and GPx, plays an important role in protecting cells from oxidative damage [19].

Glibenclamide is a second-generation sulfonylurea, which mediates hypoglycemic effect reducing the hepatic clearance which occurs by the stimulation of insulin release from the pancreatic beta cells suppressing the secretion of glucagon [20].

One of the characteristic features of chronic diabetes is lipid peroxidation. Oxidative damage induced by diabetic drug resulted in the formation of highly reactive hydroxyl radical, and this stimulates the LPO destruction and damage to the cell membrane. Treatment with this plant reduced the lipid peroxides level indicating the effective antioxidant property of the herbal drug in the tissue damage [21,22]. Due to the accumulation of superoxide anion and hydrogen peroxide, there is a reduction in the activity of CAT which result in a number of deleterious effects [23]. Administration of M. scandens increased the activities of CAT in diabetic rats.

One of the biomolecule against chemically induced toxicity is glutathione that participates in the elimination of reactive intermediates by reduction of hydroperoxides in the presence of GPx. GSH also functions in the repair of radical caused biological damage acting as a free radical scavenger and inhibits free radical-mediated lipid peroxidation process. Reduction of glutathione levels in diabetes is due to increase

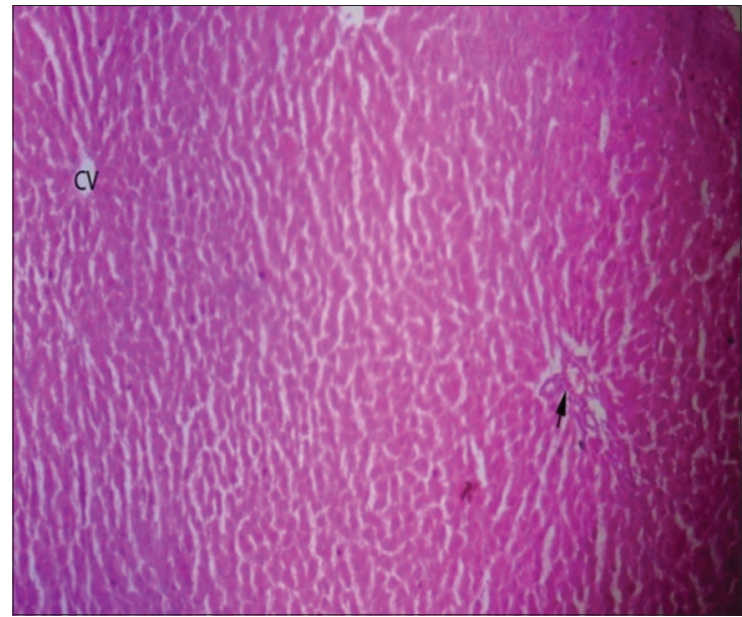

Fig. 1: Normal Control rat liver observed under high power $(\times 40)$

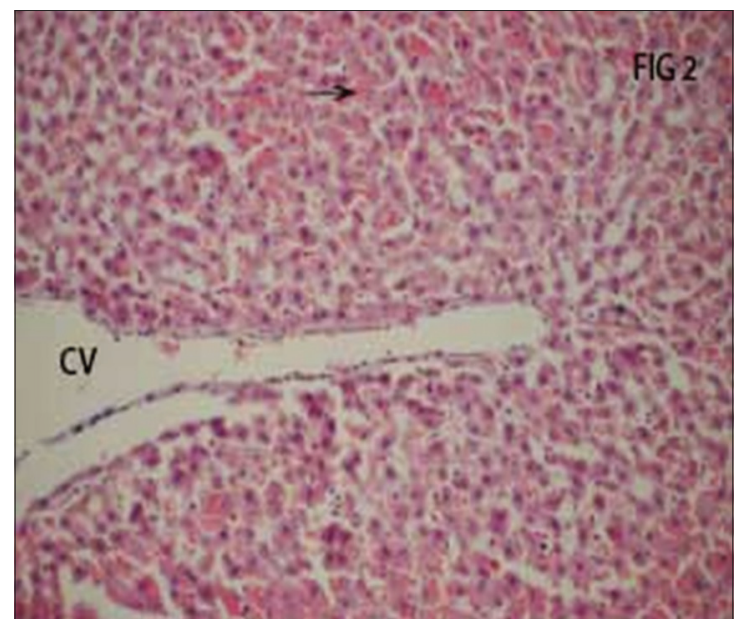

Fig. 2: Diabetic rat liver observed under high power $(\times 40)$

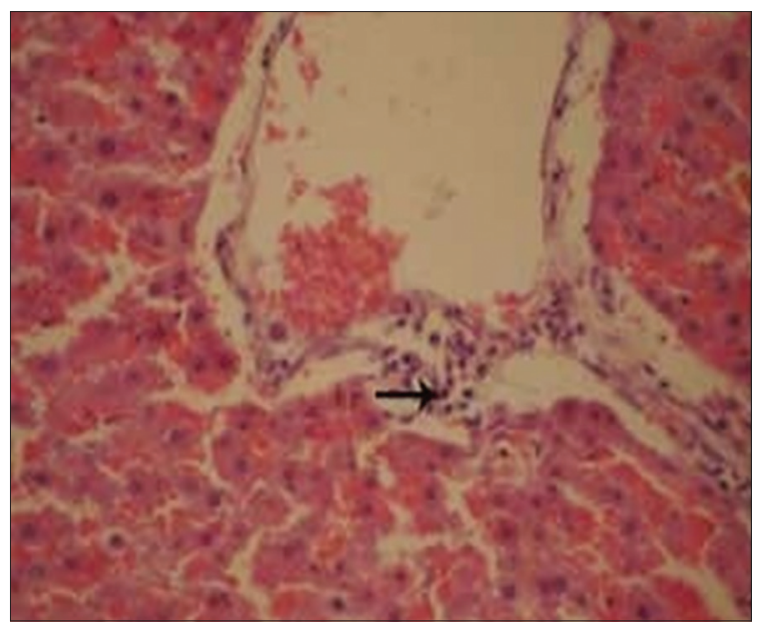

Fig. 3: Alloxan+Mikania scandens $250 \mathrm{mg} / \mathrm{kg}$ dose treated rat liver observed under high power $(\times 40)$

in oxidative stress as GSH is utilized by the GPx and where GST act as their substrate that lowers the level of GSH [24-27]. In this study, the Groups 4 and 5 resulted in significant elevation of GPX and GSH in the experimental rats.

This might reflect the antioxidant potency of $M$. scandens, which prevented glycation and inactivate GPx by reducing glucose levels. 
The overexpression of these antioxidant enzymes in diabetic rats treated with $M$. scandens implies that this potential oxidant defense is reactivated by increase capacity of detoxification by the active principles resulting in enhanced oxy radicals scavenging.

Even the histopathological observations have proven the fact of accelerated regeneration of the hepatic cells by the plant extract. Photochemical analyses showed the presence of alkaloids, tannins, saponins, flavonoids, and anthraquinones in the extracts. Some of the studies have reported that hypoglycemic and hypolipidemic activities are due to the flavonoids, alkaloids, and the tannins which are present in the extracts [28]

\section{CONCLUSION}

Results of the present study indicated that under the present experimental conditions, ethanolic extract of $M$. scandens showed antidiabetic effects against alloxan-induced liver damage in rats. Phytoconstituents present in the plant extract such as flavonoids and tannins are known to possess antidiabetic activity as reported in literature. In the present investigation, the observed antidiabetic potential of test extract may be due to the presence of similar phytochemical which was evident by preliminary screening. Further investigations are needed to understand the mechanism action.

\section{AUTHORS CONTRIBUTIONS}

Rimashree Baishya performed the experimental work, prepared the data and drafted the writeup. Anjan Adhikari is a doctor of Pharmacology Department who designed and guided the animal experiment and assessed the concerened data. Sharmistha Biswas is a Doctor of Anantomy Department who have done the histopathology slide and assessed the result of it. Soma Banerjee guided the research work and edited the writeup.

\section{CONFLICT OF INTERESTS}

The authors do not have any conflict of interest to declare.

\section{REFERENCES}

1. Burke JP, Williams K, Narayan KM, Leibson C, Haffner SM, Stern MP. A population perspective on diabetes prevention: Whom should we target for preventing weight gain? Diabetes Care 2003;26:1999-2004.

2. Olefasky JM. Diabetes mellitus In: Wyngarden JB, Smith LH, Bennett JC, editors. Text Book of Medicine. $17^{\text {th }}$ ed. Philadelphia, PA: WB Saunders; 1985. p. 1320-41.

3. Hooft R. Drug discovery and development for metabolic diseases. Drug Discov Today 2003;8:1064-6.

4. Rajaram K. Antioxidant and antidiabetic activity of Tectona grandis Linn. in alloxan induced albino rats. Asian J Pharm Clin Res 2013;6:174-7.

5. Latha S, Rajaram K, Suresh KP. Hepatoprotective and antidiabetic effect of methanol extract of Caralluma fimbriata in streptatozocin induced diabetic Albino Rats. Int J Pharm Pharm Sci 2014;6:665-68.

6. Chandra S, Dey P, Bhattacharya S. Preliminary in vitro assessment of anti-inflammatory property of Mikania scandens flower extract. J Adv Pharm Educ Res 2012;2:25-31.

7. Baral B, Bhattarai N, Vaidya GS. Pharmacological and antagonistic potentials of Mikania sp. Nepal J Sci Technol 2011;12:75-84.

8. Hajra S, Mehta A, Pandey P, John J, Mehta P. Antibacterial property of crude ethanolic extract of Mikania sp. Asian J Exp Biol Sci 2010;1:158-60.

9. Pérez-Amador MC, Ocotero VM, Balcazar RI, Jiménez FG. Phytochemical and pharmacological studies on Mikania micrantha HBK (Asteraceae). Int J Exp Bot 2010;79:77-80.

10. Trease GE, Evans WC. A Text Book of Pharmacognosy. London: Bailliere Tindall and Company Publishers; 1983. p. 343-83.

11. Crossland J. Lewis's Pharmacology. $5^{\text {th }}$ ed. London: Churchill Living Stone; 1980. p. 113-20

12. Stanely MP, Venugopal MP, Pari L. Effect of Syzigium cumini extracts on hepatic hexokinase and glucose-6-phosphatase in experimental diabetes. Phytother Res 1997;11:529-31.

13. Aebi H. Catalase. In: Bergrenyer H, editor. Methods in Enzymatic Analysis. $2^{\text {nd }}$ ed. New York: Academic Press; 1974. p. 673.

14. Beutler E, Duron O, Kelly B. Reduced glutathione estimation. J Lab Clin Med 1963;61:882-5.

15. Fraga MJ, Barren C, Carabaño R, Méndez J, De Blas JC. Effect of amount of fibre in the diet on rate of growth and digestive tract of rabbits. An INIA Serie Ganadera 1984;21:91-110.

16. Edem DO. Hypoglycemic effects of ethanolic extract of Alligator pear seed (Persea Americana Mill) in rats. Eur J Sci Res 2009;33:669-78.

17. Rerup CC. Drugs producing diabetes through damage of the insulin secreting cells. Pharmacol Rev 1970;22:485-518.

18. Aybar MJ, Sánchez Riera AN, Grau A, Sánchez SS. Hypoglycemic effect of the water extract of Smallantus sonchifolius (yacon) leaves in normal and diabetic rats. J Ethnopharmacol 2001;74:125-32.

19. Adewole SO, Ojewole JA. Protective effects of Annona muricata Linn. (Annonaceae) leaf aqueous extract on serum lipid profiles and oxidative stress in hepatocytes of streptozotocin-treated diabetic rats. Afr J Tradit Complement Altern Med 2008;6:30-41.

20. Davis SN, Granner DK. Insulin, oral agents and the pharmacology of the endocrine pancreas. In: Hardman JG, Limbard LE, Gillman AG, editors. Goodman and Gillman's the Pharmacological Basis of Therapeutics. New York: McGraw Hill Co.; 2001. p. 1679-714

21. Budin SB, Othman F, Louis SR, Bakar MA, Das S, Mohamed J. The effects of palm oil tocotrienol-rich fraction supplementation on biochemical parameters, oxidative stress and the vascular wall of streptozotocin-induced diabetic rats. Clinics (Sao Paulo) 2009;64:235-44.

22. Cemek M, Kaga S, Simsek N, Büyükokuroglu ME, Konuk M. Antihyperglycemic and antioxidative potential of Matricaria chamomilla L. in streptozotocin-induced diabetic rats. J Nat Med 2008;62:284-93.

23. Moron MS, Depierre JW, Mannervik B. Levels of glutathione, glutathione reductase and glutathione $\mathrm{S}$-transferase activities in rat lung and liver. Biochim Biophys Acta 1979;582:67-78.

24. Levy U, Zaltzber H, Amotz AB, Kanter Y, Aviram M. $\beta$-carotene affects antioxidant status in non-insulin dependent diabetes mellitus. Pathophysiology 1999;6:157-61.

25. Chance B, Greenstein DS, Roughton FJ. The mechanism of catalase action. I. Steady-state analysis. Arch Biochem Biophys 1952;37:301-21.

26. Searle AJ, Willson RL. Glutathione peroxidase: Effect of superoxide, hydroxyl and bromine free radicals on enzyme activity. Int J Radiat Biol Relat Stud Phys Chem Med 1980;37:213-7

27. Sözmen EY, Sözmen B, Delen Y, Onat T. Catalase/superoxide dismutase (SOD) and catalase/paraoxonase (PON) ratios may implicate poor glycemic control. Arch Med Res 2001;32:283-7.

28. Satyanarayana K, Mangathayaru V, Shreekanth J, Venkateshwaralu V, Kokate CK. Studies on the hypoglycaemic and the cardio tonic effects of the roots of Cocclus hirsutus. J Pharm Sci 2001;63:30-5. 